\title{
Surgical correction of strabismus in Lambert-Eaton myasthenic syndrome: case reports
}

\author{
Correção cirúrgica do estrabismo na síndrome de \\ Lambert-Eaton: relato de dois casos
}

\footnotetext{
Trabalho realizado nas clínicas particulares dos dois autores - USP - Ribeirão Preto (SP) - UNIFESP - São Paulo (SP) - Brasil.

Doutora em Oftalmologia pela Faculdade de Medicina de Ribeirão Preto da Universidade de São Paulo - USPRibeirão Preto (SP) - Brasil. Chefe do setor de Estrabismo do Instituto de Oftalmologia Tadeu Cvintal, São Paulo (SP) - Brasil.

${ }^{2}$ Doutor em Oftalmologia pela Universidade Federal de São Paulo da UNIFESP - São Paulo (SP) - Brasil. Chefe da Seção de Estrabismo do Departamento de Oftalmologia da Santa Casa de Misericórdia de São Paulo, São Paulo (SP) - Brasil.

Autor correspondente: Fernanda Teixeira Krieger. Rua Maria Figueiredo, 283 - São Paulo (SP) CEP 04002-001 E-mail: ftskrieger@hotmail.com

Recebido para publicação em 17.03.2008

Última versão recebida em 16.11.2008

Aprovação em 17.11.2008

Nota Editorial: Depois de concluída a análise do artigo sob sigilo editorial e com a anuência da Dra. Mônica Fialho Cronemberger sobre a divulgação de seu nome como revisora, agradecemos sua participação neste processo.
} 
evaluation, a $40^{\Delta}$ right exotropia was observed with limitation of adduction (-3) and a compensatory face turned to the left (Figure 1A and 1B). She had, 10 years before, experienced an episode of vertical diplopia simulating a left inferior rectus paresis with normal results after investigation (CT scan, tensilon test). At that time, after a one-year period of unchanged deviation a left superior rectus recession was performed. She was straight in all positions of gaze. This new episode was again investigated by a neurologist and the electromyography revealed a $160 \%$ amplitude increment after a train of 10 stimuli delivered at $50 \mathrm{~Hz}$ in the left median nerve. The deviation was stable for nine months and a recess-resect procedure was then performed in the right eye (RE) with adjustable sutures $(7 \mathrm{~mm}$ lateral rectus recession and $5 \mathrm{~mm}$ medial rectus resection). There was no need for adjustment and she became, during 16 months of follow-up, orthotropic in all positions of gaze, with no compensatory face turned to the left and no limitation of adduction and abduction (Figure 1C and 1D).

\section{Case 2}

A 64-year-old-woman presented with a one-month history of generalized weakness and horizontal diplopia, associated with a dry mouth. She had been treated for small cell lung cancer about four years before and, since then, has been followed with no evidence of tumor recurrence or metastasis. Ocular examination revealed a best corrected visual acuity of 20/20 in both eyes, normal pupilar reflexes and absence of blepharoptosis. There was a face turn to the left and she presented a right $45^{\Delta}$ exotropia with $8^{\Delta}$ hypotropia in the primary position, and this eye could not adduct beyond midline (Figure 2A and 2B). No abnormalities were found on orbital ultrasound and computed tomography. Repetitive nerve conduction test was performed with the recording electrodes over abductor digiti minimi. The compound muscle action potential of right ulnar nerve at rest was $4,8 \mathrm{mV}$. At $3 \mathrm{~Hz}$ stimulation, a $21 \%$ reduction in this action potential was observed, and a $316 \%$ increment at $30 \mathrm{~Hz}(20.0 \mathrm{mV})$. The serum titer of acetylcholine receptor antibodies was normal and there was no response to acetylcholinesterase inhibitor test. Magnetic resonance imaging demonstrated recurrence of lung tumor. She underwent chemotherapy with improvement of limb weakness and dry mouth but not of diplopia. After a one-year period of unchanged deviation, she underwent $8 \mathrm{~mm}$ lateral rectus recession and $7 \mathrm{~mm}$ medial rectus resection with $5 \mathrm{~mm}$ transposition upward of both insertions under topical anesthesia. On examination at 13 months of follow-up there was no compensatory head position and versions were normalized and the patient presented with orthotropia in all positions of gaze (Figure 2C and 2D).

\section{DISCUSSION}

Our patients presented isolated medial rectus paresis without other ocular signs and symptoms. In most reports in
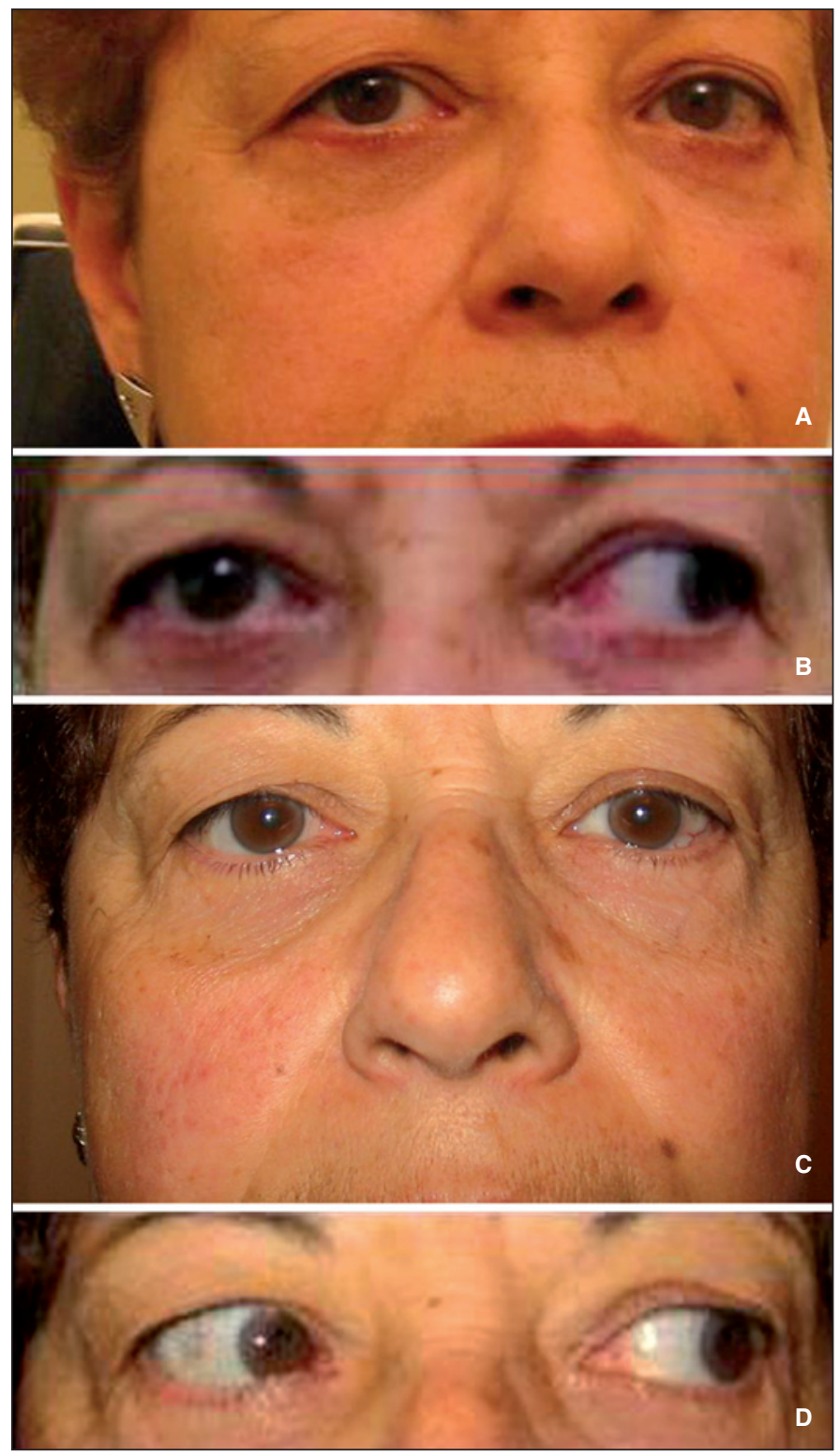

Case 1: Figure 1 - A) Preoperative photograph demonstrating face turned to the left; B) preoperative photograph in left gaze demonstrating limitation of adduction (-3) in the right eye; C) postoperative photograph in primary position without compensatory head position; D) postoperative photograph in left gaze demonstrating full adduction in the right eye

the literature, ophthalmoparesis with diplopia is not characteristic $^{(1,4-5,8)}$, whereas some authors ${ }^{(6)}$ suggest that ocular findings in this syndrome are more common and cannot be used to exclude the diagnosis. This syndrome can be misdiagnosed as myasthenia gravis ${ }^{(1-9)}$. Ptosis in Lambert-Eaton is usually mild and never of the severity seen in myasthenia gravis. The distribution of muscle weakness is different in both disorders: in myasthenia, at the onset, the presence of only ocular symptoms is common, and muscle weakness tends to develop in a craniocaudal direction. In LambertEaton myasthenic syndrome the weakness develops in the opposite direction ${ }^{(5)}$. In addition, decreased tendon reflexes 

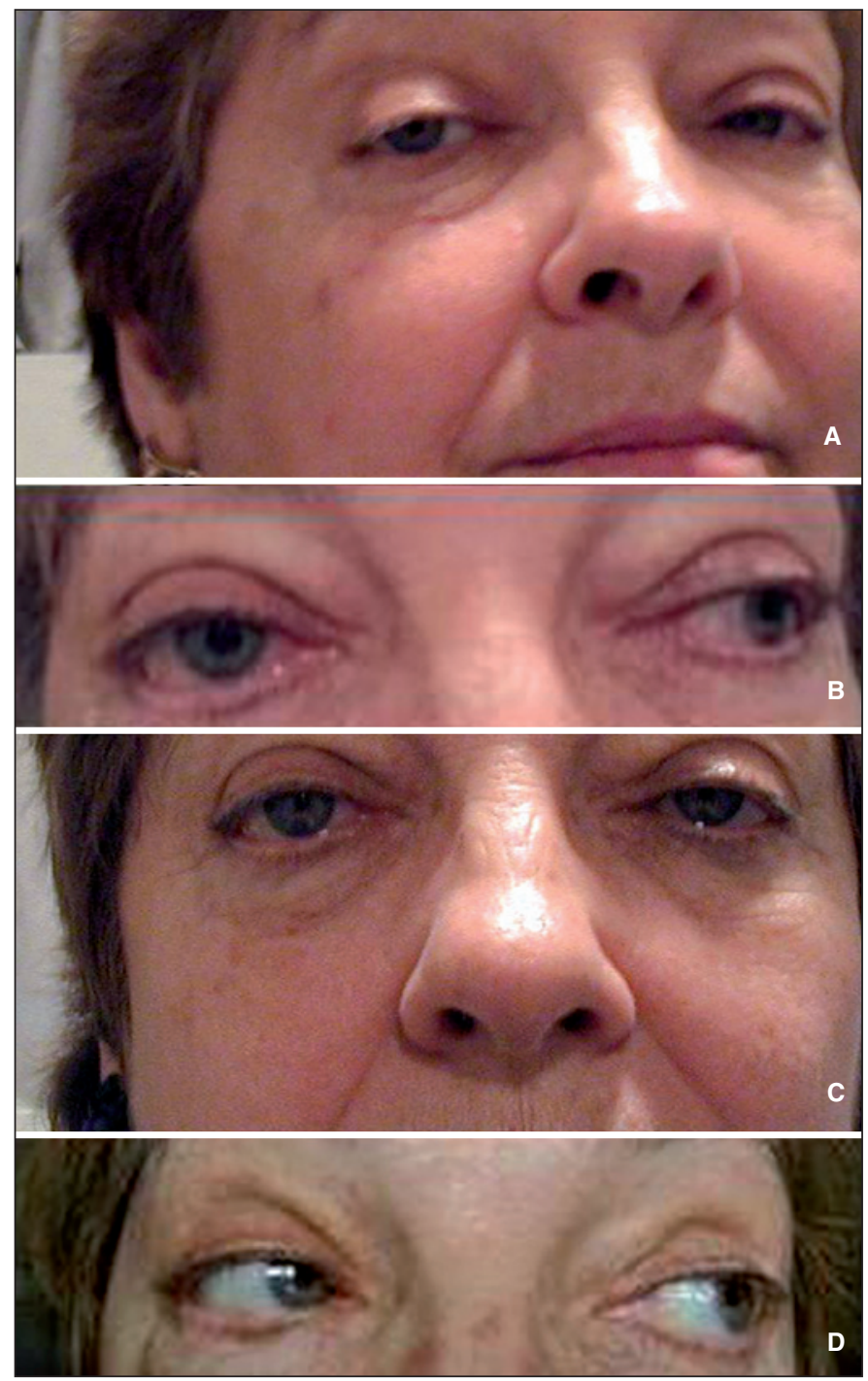

Case 2: Figure 2 - A) Preoperative photograph demonstrating face turned to the left; B) preoperative photograph in left gaze demonstrating limitation of adduction (-4) in the right eye; C) postoperative photograph in primary position without compensatory head position; $D$ ) postoperative photograph in left gaze demonstrating full adduction in the right eye

and autonomic dysfunction are features of this syndrome. Limb weakness confined to the arms is only found in generalized myasthenia and not in Lambert-Eaton syndrome. The presence of malignancy, most frequently small cell lung cancer, is related to Lambert-Eaton syndrome. If a tumor is not found 2 years after symptom onset, cancer is unlikely, and in virtually all cases cancer is detected within 4 years. The diagnosis of myasthenia is confirmed by the presence of acetylcholine receptor antibodies, a decrement of larger than
$10 \%$ on repetitive nerve stimulation and an unequivocal positive response to acetylcholinesterase inhibitor test. Lambert-Eaton diagnosis is based on the presence of serum antivoltage gated calcium channel antibodies or an increment on high frequency repetitive nerve stimulation or after maximum voluntary contraction. In summary, in addition to the difference in muscle weakness distribution, the following are common in Lambert-Eaton syndrome: dysautonomia, decreased or absent reflexes, association with cancer, specifically small cell lung, absence of antibodies to actetylcholine receptors, presence of antibodies to voltage-gated calcium channel and electrophysiological findings.

In both cases presented here there was only limitation of adduction in the RE (right eye) with diplopia, which was relieved with a left face turn. Most reports in the literature refer to diplopia but without ophthalmoparesis ${ }^{(1,6,8)}$. In a study of 50 cases of Lambert-Eaton syndrome, $70 \%$ of them had transient diplopia but none of them had signs of ocular paresis ${ }^{(1)}$. In our cases, blepharoptosis was not present, in contrast to $54 \%$ of these 50 cases. The extraocular muscle involvement may be detected only through eletrooculography, which demonstrates abnormal velocities and this could explain the complaint of diplopia without apparent extraocular paresis $^{(9)}$.

Despite the presence of a paretic medial rectus muscle, a resection was carried out in both cases. This procedure was chosen after conversations with patients with regard to spare time. After extraocular muscle surgery, adduction improved considerably in both cases. The head turn and diplopia in the primary position was resolved, allowing a better quality of life. The low prognosis of life in patients with lung carcinoma should not be a contraindication to surgery, unless impaired systemic conditions exist.

To our knowledge, this is the first report of surgery for extraocular muscle paresis in Lambert-Eaton myasthenic syndrome*.

\section{RESUMO}

A síndrome de Lambert-Eaton é um distúrbio autoimune raro e adquirido. Apresentamos duas pacientes com paresia do reto medial como única manifestação ocular. Após retrocesso do reto lateral e ressecção do reto medial, unilateral, ambas as pacientes apresentaram normalização da adução. Até onde sabemos, este é o primeiro relato de cirurgia para paresia do reto medial na síndrome de Lambert-Eaton.

Descritores: Síndrome miastênica de Lambert-Eaton; Miastenia grave; Estrabismo/cirurgia; Paresia; Humano; Feminino; Meia-idade; Relato de casos [Tipo de publicação]

\footnotetext{
A systematic search of the literature published in English, Spanish and Portuguese languages between 1965 and 2007 was performed including MEDLINE, EMBASE, LILACS and SciElo. Search terms included: Lambert-Eaton syndrome, mystenia, ocular muscle weakness, ocular palsies, eye muscle, strabismus, surgery.
} 


\section{REFERENCES}

1. O'Neil JH, Murray NM, Newsom-Davis J. The Lambert-Eaton myasthenic syndrome. A review of 50 cases. Brain. 1988;111(Pt 3):577-96.

2. Oh SJ. The Eaton-Lambert syndrome in ocular myasthenia gravis. Arch Neurol. 1974;31(3):183-6.

3. Bataller L, Dalmau J. Neuro-ophthalmology and paraneoplastic syndromes. Curr Opin Neurol. 2004;17(1):3-8.

4. Kanzato N, Motomura M, Suehara M, Arimura K. Lambert-Eaton myasthenic syndrome with ophthalmoparesis and pseudoblepharospasm. Muscle Nerve. 1999;22(12):1727-30.

5. Wirtz PW, Sotodeh M, Nijnuis M, Van Doorn PA, Van Engelen BG, Hintzen $\mathrm{RQ}$, et al. Difference in distribution of muscle weakness between myasthenia gravis and the Lambert-Eaton myasthenic syndrome. J Neurol Neurosurg Psychiatry. 2002;73(6):766-8.

6. Burns TM, Russel JA, LaChance DH, Jones HR. Oculobulbar involvement is typical with Lambert-Eaton myasthenic syndrome. Ann Neurol. 2003;53(2):270-3. Comment in: Ann Neurol. 2003;54(1):135-6; author reply 136-7.

7. Rudnicki SA. Lambert-Eaton myasthenic syndrome with pure ocular weakness. Neurology. 2007;68(21):1863-4. Comment in: Neurology. 2008;70(1):876; author reply 86-7.

8. Stickler DE, Sanders DB. Lambert-Eaton myasthenic syndrome. [Internet]. [cited 2007 Jan 10]. Available from: http://www.emedicine.com/NEURO/topic181.htm.

9. Breen LA, Gutmann L, Brick JF, Riggs JR. Paradoxical lid elevation with sustained upgaze: a sign of Lambert-Eaton syndrome. Muscle Nerve. 1991;14(9): 863-6.

10. Fukunaga H, Engel AG, Lang B, Newsom-Davis J, Vincent A. Passive transfer of Lambert-Eaton myasthenic syndrome with IgG from man to mouse depletes the presynaptic membrane active zones. Proc Natl Acad Sci USA. 1983;80(24): 7636-40.

11. Oh SJ, Kurokawa K, Claussen GC, Ryan HF Jr. Electrophysiological diagnostic criteria of Lambert-Eaton myasthenic syndrome. Muscle Nerve. 2005; 32(4):515-20. (Footnotes). 